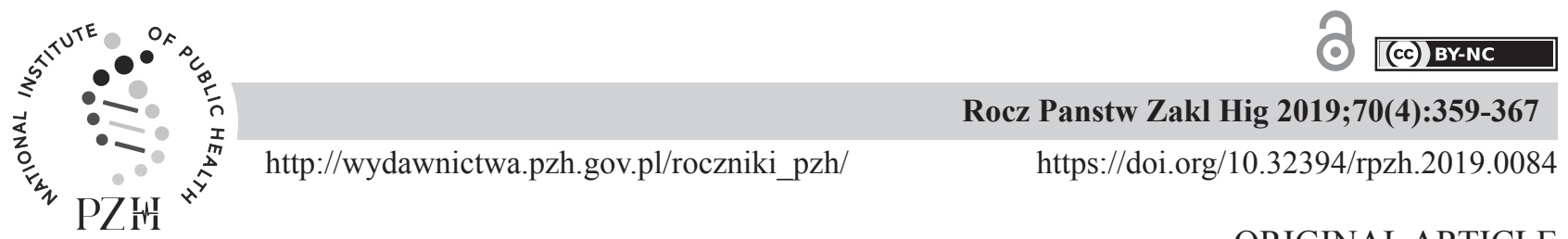

ORIGINAL ARTICLE

\title{
QUANTITATIVE ASSESSMENT OF NUTRITION AND NUTRITIONAL STATUS OF PATIENTS WITH CELIAC DISEASE AGED 13-18
}

\author{
Justyna Kikut ${ }^{1}$, Nina Koneckal, Matgorzata Szczuko \\ ${ }^{1}$ Pomeranian Medical University in Szczecin, Department of Human Nutrition and Metabolomics, \\ Broniewskiego str. 24, 71-460 Szczecin, Poland
}

\begin{abstract}
Background. Celiac disease is an autoimmune disease that affects about $1 \%$ of the European population and $0.3-1.3 \%$ of the world's population. The only method of treatment is introduction of a gluten-free diet.

Objective. The aim of the study was to assess the nutrition of adolescents with celiac disease and to assess their nutritional status. Materials and methods. The study group comprised 24 patients with diagnosed celiac disease. The diagnosis was based on biopsy, serological tests and, in some cases, genetic tests. Anthropometric measurements included height, which was respectively 161.9 $\pm 12.43 \mathrm{~cm}$ in boys and $163.6 \pm 9.03 \mathrm{~cm}$ in girls, and body weight oscillating between $56.55 \pm 16.24 \mathrm{~kg}$ for boys and $52.62 \pm 10.92 \mathrm{~kg}$ for girls. To assess the way of nutrition used an individually prepared questionnaire including an interview from the last $24 \mathrm{~h}$. The menus were analyzed using the Dieta $5 \mathrm{~d}$ program. The statistical analysis of the data was made using Statistica 12 program.

Results. Gluten-free diet contributes to the occurrence of caloric deficiencies up to $36 \%$. It was found inadequate intake of dietary fiber, for girls $15.45 \pm 9.84 \mathrm{~g}$ and $14.41 \pm 4.73 \mathrm{~g}$ for boys. It has been observed too low intake of ingredients such as calcium $(565.65 \pm 347.41 \mathrm{mg})$, magnesium $(223.41 \pm 73.84 \mathrm{mg})$, vitamin $\mathrm{D}(1.34 \pm 1.28 \mu \mathrm{g})$ and $\mathrm{E}(5.05 \pm 2.32 \mathrm{mg})$ as well as potassium $(2848.67 \pm 1132.07 \mathrm{mg})$, iron $(7.62 \pm 2.05 \mathrm{mg})$, zinc $(7.11 \pm 2.41 \mathrm{mg})$ and thiamine $(0.87 \pm 0.38 \mathrm{mg})$. The ingredients such as riboflavin, niacin, pyridoxine, cobalamin, and vitamins $\mathrm{C}$ and $\mathrm{A}$ were consumed in the right amount.

Conclusions. Incorrectly used gluten-free diet may contribute to the recurrence of the disease. Chronic inadequate intake of fiber can lead to constipation. A deficiency of many nutrients can result in impaired development of the young organism such as anemia, growth retardation or osteoporosis.
\end{abstract}

Key words: celiac disease, gluten enteropathy, nutrition, nutritional status, teenagers, gluten-free diet

\section{STRESZCZENIE}

Wprowadzenie. Celiakia należy do chorób autoimmunologicznych, która dotyka ok. 1\% populacji Europy oraz 0,3-1,3\% populacji światowej. Jedyną metodą leczenia jest zastosowanie diety bezglutenowej.

Cel. Celem badania była ocena sposobu żywienia nastolatków z chorobą trzewną oraz ocena ich stanu odżywienia.

Materiały i metody. Grupę badaną stanowiło 24 pacjentów ze zdiagnozowaną chorobą trzewną. Diagnozę postawiono na podstawie biopsji, badań serologicznych oraz w niektórych przypadkach badań genetycznych. Pomiary antropometryczne obejmowały wzrost, który wynosił odpowiednio $161,9 \pm 12,43 \mathrm{~cm}$ u chłopców oraz 163,6 $\pm 9,03 \mathrm{~cm}$ u dziewcząt a także masę ciała oscylującą pomiędzy 56,55 $\pm 16,24 \mathrm{~kg}$ u chłopców oraz 52,62 $\pm 10,92 \mathrm{~kg}$ u dziewcząt. Do oceny sposobu żywienia wykorzystano indywidulanie przygotowaną ankietę obejmującą wywiad z ostatnich 24 godzin. Jadłospisy analizowano za pomocą programu dietetycznego Dieta 5d. Analizę statystyczną wykonano w programie Statistica 12.

Wyniki. Dieta bezglutenowa wprowadzała niedobory kaloryczne sięgające nawet 36\%. Stwierdzono niedostateczne spożycie błonnika pokarmowego wynoszące dla dziewcząt 15,45 $\pm 9,84 \mathrm{~g}$ oraz 14,41 $\pm 4,73 \mathrm{~g}$ dla chłopców. Zaobserwowano zbyt niskie spożycie wapnia $(565,65 \pm 347,41 \mathrm{mg})$, magnezu $(223,41 \pm 73,84 \mathrm{mg})$, witamin $\mathrm{D}(1,34 \pm 1,28 \mu \mathrm{g}) \mathrm{i} \mathrm{E}(5,05 \pm 2,32 \mathrm{mg})$ oraz kwasu foliowego $(190,8 \pm 69,91 \mu \mathrm{g})$ a także potasu $(2848,67 \pm 1132,07 \mathrm{mg})$, żelaza $(7,62 \pm 2,05 \mathrm{mg})$, cynku $(7,11 \pm 2,41 \mathrm{mg})$ i tiaminy $(0,87 \pm 0,38 \mathrm{mg})$. W odpowiedniej ilości były spożywane takie składniki jak ryboflawina, niacyna, pirydoksyna, kobalamina oraz witaminy $\mathrm{C}$ i A. Wnioski. Nieprawidłowo prowadzona dieta bezglutenowa może przyczynić się do wystąpienia nawrotów choroby. Przewlekłe niedostateczne spożycie błonnika może prowadzić do wystąpienia zaparć. Należałoby wdrożyć suplementację witaminy D, wapnia oraz magnezu a także wzbogacić dietę w foliany oraz witaminę E a także potas, żelazo i cynk. Niedobór wielu składników odżywczych może skutkować zaburzeniami rozwoju młodego organizmu takim jak niedokrwistość, zatrzymanie wzrostu czy osteoporoza.

\section{Slowa kluczowe: celiakia, enteropatia glutenowa, żywienie, stan odżywienia, nastolatkowie, dieta bezglutenowa}

Corresponding author: Małgorzata Szczuko, Pomorski Uniwersytet Medyczny w Szczecinie, Katedra i Zakład Żywienia Człowieka i Metabolomiki / Pomeranian Medical University in Szczecin, Department of Human Nutrition and Metabolomics, Broniewskiego 24, 71-460 Szczecin, Poland, e-mail: malgorzata.szczuko@pum.edu.p1

(c) Copyright by the National Institute of Public Health - National Institute of Hygiene 


\section{INTRODUCTION}

Celiac disease, also known as gluten enteropathy or celiac disease, is an autoimmune disorder of the small intestine with genetic background. It is associated with changes in the intestinal mucosa characterized by atrophy of the intestinal villi. This results in the occurrence of many deficiencies caused by a reduction in ability to absorb nutrients. The immune response is triggered in response to the protein - gluten fraction, and in particular to its prolamine - gliadin. Also prolamins contained in rye (secalins) and in barley (hordeins) and in oats (avenins) are responsible for causing an abnormal reaction. However, $90 \%$ oat is a safe crop for patients with celiac disease. Currently, the only treatment option is the introduction of a gluten-free $\operatorname{diet}[17,40]$.

Celiac disease affects about $1 \%$ of the European population and the incidence is still increasing [18]. In Poland, no records of patients are kept, however, it is presumed that enteropathy may affect up to 1 in 100 people [21]. Over the years, celiac disease was considered a disease of childhood where the peak incidence at the age of 5 , and today more often seen as a high incidence in adults aged 35-55 years [21]. Celiac disease twice as often occurs in women than in men [13]. Symptoms of the disease are closely related to both the patient's age and duration of the disease or symptoms from outside the digestive tract.

There are 4 types of celiac disease:

- Typical - especially in young children; villus atrophy is observed, whereas the symptoms mainly affect the gastrointestinal tract and are diarrhea and bloating [16];

- Atypical - it is diagnosed most often in adolescents, we also observe villus atrophy, and the prevailing symptoms are outside the gastrointestinal tract; often deficiencies of such elements as iron or vitamin B12 are noted, as well as co-occurring osteoporosis, chronic inflammation or infertility [35];

- Silent - characterized by asymptomatic course of the disease, however, as in the above forms, villus atrophy is also observed;

- Latent - normal intestinal mucosa and no symptoms of the disease, however, there is a probability of future celiac disease $[16,26]$.

In the course of enteropathy, symptoms such as growth deficiency or delayed development, as well as co-occurring liver diseases, are also observed. During the diagnosis of children, even $26-57 \%$ of them have an elevated level of aminotransferases [37]. Nonspecific symptoms also include neurological disorders and the occurrence of "brain fog", which is characterised by memory loss and decreased concentration [29].
Celiac diagnosis is based on specific serological tests, including antibodies against endomysium and anti-transglutaminase tissue $[6,15]$. Serological tests are used not only for diagnosis but also for subsequent monitoring of compliance with a gluten-free diet [16]. The golden standard in the diagnosis of celiac disease is the biopsy [11]. During the biopsy, 4-5 samples are collected from several areas of the small intestine, thus determining the size of changes that have occurred in the mucosa. The severity of the symptoms will be the greater the larger intestinal area is affected. The Marsh scale is used for microscopic evaluation of collected specimens. This scale consists of 6 grades where 0 means no changes in the mucosa, while class 3 with subclasses abc associated with the presence of lesion [9]. Genetic tests for the presence of HLA DQ2 / 8 specific haplotypes for enteropathy are also used for diagnostics. Doing these tests, in certain cases, eg. the family load genotype, can prevent further tested [15]. Gluten-free diet counts as elimination diets. It mainly involves the conversion of common cereals - wheat, barley and rye to those that naturally do not contain harmful to the patients protein, which is gluten or to those from which it was removed through technological processes [24]. In the process of introducing a patient to a gluten-free diet, the patient should be appropriately educated as to preparing the dishes. Particular attention should be given to the possibility gluten contamination of the product during processing in the kitchen [17]. A gluten-free product is one in which the gluten content does not exceed $20 \mathrm{mg}$ per kg of product or one that does not naturally contain this protein. A product with a very low gluten content is the one where the value of this protein does not exceed $100 \mathrm{mg}$ per $\mathrm{kg}$ of product [4].

Recommendations regarding ingredients such as fats, carbohydrates and protein are consistent with those in a healthy diet model. Protein intake should be approx. $15 \%$ of the daily ration, and its main sources in the diet should be a dairy, meat, fish and legumes. The fat content in the diet should be up to $30 \%$, while carbohydrates should be around $50 \%$. To prevent possible deficiencies in the diet of patients, it is necessary to ensure the right amount of vegetables and fruits on the menu [34].

It was observed that inadequate consumption of vitamins, such as folic acid, cobalamin or pyridoxine is closely related to increased levels of homocysteine. Equation of state of intestinal mucosa, and the use of a gluten-free diet normalized homocysteine levels [22].

To enrich the diet of patients and prevent the occurrence of shortages, should include in the menu naturally gluten-free pseudo-grains, which include 
amaranth, corn, millet, quinoa, tapioca, teff and rice. These cereals are the source, among others amino acids, calcium or B group vitamins [30].

Celiac disease is one of the most frequently occurring genetically determined diseases, current data suggest an increase in morbidity, especially among children and adolescents. The only method of treatment is the introduction of a strict gluten-free diet, which belongs to the elimination diets and if not properly carried out, can lead to numerous nutritional deficiencies. Children and adolescents are a group of patients in whom it is particularly important to ensure an adequate supply of nutrients to ensure adequate growth and development.

The aim of the work was to show through analysis of the nutrition and nutritional status of teenagers the biggest health risk that could result from the use of a diet eliminating gluten. In addition, the specific objectives included:

- analysis of the composition of menus and the way of feeding young people

- analysis of nutritional status by anthropometric methods

Table 1. Characteristics of the studied group

\begin{tabular}{|c|c|c|c|c|}
\hline & $\begin{array}{c}\text { Girls } \\
\text { (average }+ \text { SD) }\end{array}$ & $\begin{array}{c}\text { Boys } \\
\text { (average +SD) }\end{array}$ & $\begin{array}{c}\text { Average of the study } \\
\text { group }\end{array}$ & $\mathrm{p}$ \\
\hline Age (years) & $15.46 \pm 1.447$ & $14.6 \pm 1.430$ & $15.04 \pm 1.46$ & 0.217 \\
\hline Weight (kg) & $52.6 \pm 10.918$ & $56.55 \pm 16.239$ & $54.26 \pm 13.21$ & 0.485 \\
\hline Height (cm) & $163.6 \pm 9.027$ & $161.9 \pm 12.432$ & $162.92 \pm 10.36$ & 0.694 \\
\hline Body mass index (BMI) & $19.5 \pm 2.74$ & $21.7 \pm 3.63$ & $20.4 \pm 3.23$ & 0.575 \\
\hline
\end{tabular}

The most frequently reported comorbidities include type 1 diabetes, hypothyroidism, reflux, anemia and asthma. A questionnaire including an interview on the last 24 hours of consumption, belonging to intelligence and quality-quantity methods was used to assess the diet. Anthropometric measurements: height, weight, age, were collected during the visit to the nearest $0.5 \mathrm{~cm}$ and $0.5 \mathrm{~kg}$. The questionnaire included questions about the occurrence of allergies, food intolerances, medications and supplements, and physical activity of the child. In order to obtain precise information on the size of portions of meals consumed, the Photo Album of products and dishes which is recommended by the Institute of Food and

\section{MATERIAL AND METHODS}

The study group consisted of 24 patients of the Gastroenterology Outpatient Clinic of the Independent Public Clinical Hospital No. 1.prof. Tadeusz Sokołowski of the Pomeranian Medical University in Szczecin. The inclusion criteria was based on disease-positive serology tests, intestinal biopsies (four-point) and in some cases genetic tests (DQ2 and DQ8 and DQ2.5). However, the exclusion criterion was age (below 10 and above 18 years of age). In the study group there were 14 girls and 10 boys. The average age of patients was $15.3 \pm 1.45$ and $14.6 \pm 1.43$. Anthropometric measurements were also taken, including an increase of $163.6 \pm 9,027 \mathrm{~cm}$ in girls and $161.9 \pm 12.43 \mathrm{~cm}$ in boys, as well as a body weight of $52.62 \pm 10.92 \mathrm{~kg}$ for girls and $56.55 \pm$ respectively. $16.24 \mathrm{~kg}$ for boys (Table 1). Anthropometric measurements were made by qualified hospital staff. The study was not a medical experiment, it was completely non-invasive, it was based on an interview, which was obtained by the approval of the PUM Bioethical Committee No. KB-0012/116/15. Interviews were carried out with the written consent and in the presence of parents.

Nutrition (IŻŻ) [38]. The obtained anthropometric data such as height and body weight were analyzed using centiles of the OLA and OLAF project recommended by the Children's Memorial Health Institute (Figures 1 and 2). The analysis of menus was made in the Dieta $5 \mathrm{~d}$ program recommended by the Food and Nutrition Institute. The obtained data was compared to Nutrition Standards for the Polish population, edited by Jarosz [12]. The results were interpreted on the basis of norms consistent with the average age of the entire group of 13-15 years. Data were statistically analyzed in the program Statistica 12. 


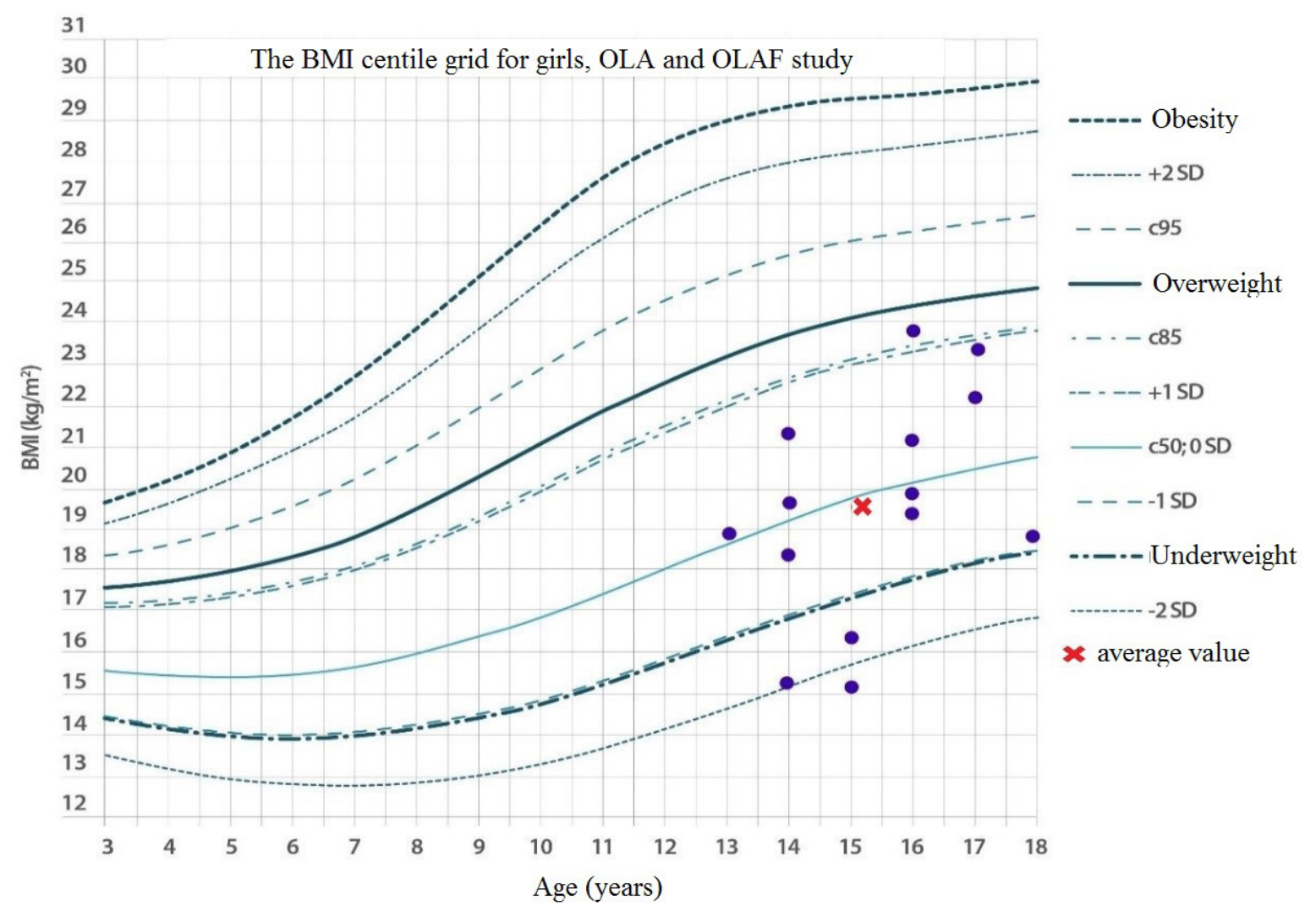

Figure 1. Body mass index (BMI) for girls

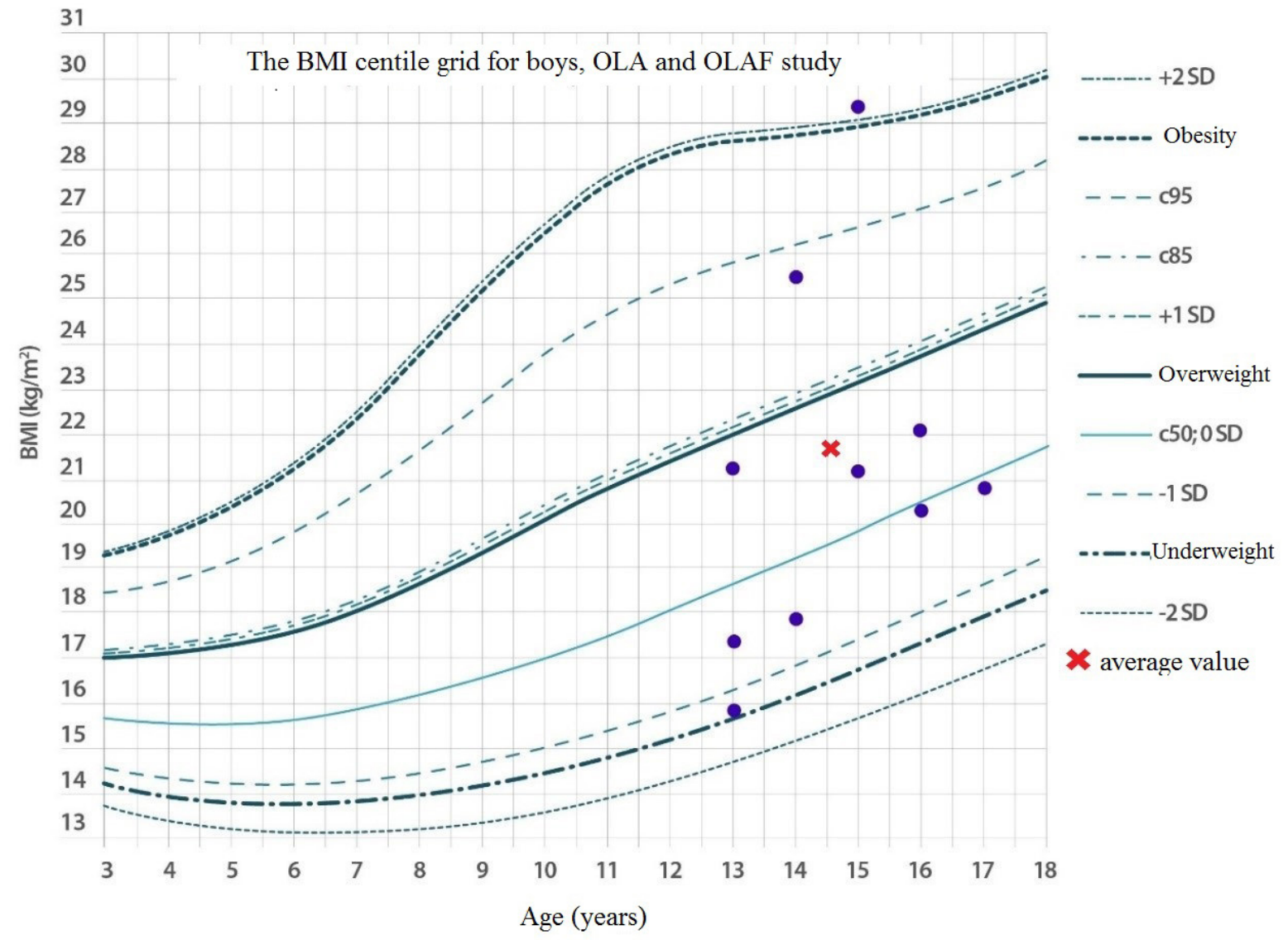

Figure 2. Body mass index (BMI) for boys 


\section{RESULTS}

Analysis of anthropometric data including body mass index (BMI) and age were related to the percentile charts separately for sex. 7 out of 14 girls were within accepted as the norm, and 7 were below the 50 percentile, of which 3 have extreme underweight. In the group of boys 7 were within 50 percentile, 1 was underweight while 2 boys were successively overweight and obese. Evaluation of nutritional status was related to the average age of the group, which was $15.04 \pm 1.46$. The level of the average demand for the group (estimated average requirement - EAR) was used for this purpose. For components for which this level has not been defined adopted adequate intake level (AI). For the total carbohydrate content, reference was made to the level of recommended RDA consumption. In relation to energy, fat, saturated fatty acids and cholesterol, the recommendations by the Institute of Food and Nutrition were used.

Both in the group of boys and in the group of girls, the energy consumption was lower than the daily demand, which was implemented at the level of $60-70 \%$ (Table 2). A significant excess was observed for intakes of saturated fatty acids in the two groups, despite low intakes of total fat. There was also a relatively high cholesterol intake in the boys' group. In both groups, fiber intake was significantly below the recommended standards of consumption. Both minerals and vitamins in both groups were lower than the recommended value (Table 3). Daily demand for calcium was only $46 \%$ for girls and $59 \%$ for boys and for folates similarly $58 \%$ and $56 \%$. Similarly, magnesium intake in both groups remained at the level of $70 \%$ in relation to the recommendations of the Institute of Food and Nutrition. Other components which are also present in quantities deficit is vitamin E, D and thiamine. In addition, a deficiency of components such as sodium, potassium, iron, zinc and iodine was also observed (Table 3 ). In boys, lower values of manganese and higher values of phosphorus were noted. A reverse relationship was observed in the group of girls. A statistically significant difference between the groups was recorded in the consumption of total protein and animal protein, with higher intakes of protein was observed in boys. The percentage of energy from both protein, fat and carbohydrates in both groups was correct (Table 4).

Table 2. Comparison of the mean energy intake, cholesterol, fiber and nutrients

\begin{tabular}{|c|c|c|c|c|}
\hline Factor & EAR & Girls & Boys & $\mathrm{p}$ \\
\hline Energy (kcal) & $2450 / 3000 *$ & 1694.348 & 1928.268 & NS \\
\hline Lipids (g) & - & 56.371 & 58.675 & NS \\
\hline SFA (g) & $\begin{array}{l}13.6-16.3 / \\
16.8-20.1^{*}\end{array}$ & 24.518 & 23.917 & NS \\
\hline MUFA (g) & - & 18.171 & 20.431 & NS \\
\hline PUFA (g) & - & 5.871 & 5.735 & NS \\
\hline Cholesterol (mg) & $\max .300$ & 293.954 & 311.181 & NS \\
\hline Carbohydrates (g) & $130^{\#}$ & 250.818 & 281.593 & NS \\
\hline Saccharose (g) & 60 & 46.246 & 54.323 & NS \\
\hline Lactose (g) & - & 7.393 & 5.635 & NS \\
\hline Dietary fibre $(\mathrm{g})$ & $19 * *$ & 15.449 & 14.410 & NS \\
\hline Protein $(g)$ & $43 / 45^{*}$ & 59.237 & 79.819 & 0.032 \\
\hline Animal protein $(\mathrm{g})$ & - & 43.975 & 63.123 & 0.039 \\
\hline Plant protein (g) & - & 13.621 & 14.230 & NS \\
\hline
\end{tabular}

EAR - Estimate Average Requirement; NS - not statistically significant, * - with gender and age distinction - girls / boys; ** - including guidelines for patients with celiac disease 
Table 3. Comparison of the average consumption of minerals and vitamins

\begin{tabular}{|c|c|c|c|c|}
\hline Factor & EAR & Girls & Boys & $\mathrm{p}$ \\
\hline $\mathrm{Na}(\mathrm{mg})$ & $2552 / 2944^{*}$ & 2062.815 & 2826.544 & NS \\
\hline $\mathrm{K}(\mathrm{mg})$ & 3000 & 2756.099 & 2978.275 & NS \\
\hline $\mathrm{Ca}(\mathrm{mg})$ & 1100 & 504.827 & 650.798 & NS \\
\hline $\mathrm{P}(\mathrm{mg})$ & 1050 & 988.798 & 1238.091 & NS \\
\hline $\mathrm{Mg}(\mathrm{mg})$ & $300 / 340 *$ & 210.653 & 241.268 & NS \\
\hline $\mathrm{Fe}(\mathrm{mg})$ & 8 & 7.52 & 7.765 & NS \\
\hline $\mathrm{Zn}(\mathrm{mg})$ & $7.3 / 8.5^{*}$ & 6.757 & 7.603 & NS \\
\hline $\mathrm{Cu}(\mathrm{mg})$ & 0.7 & 0.786 & 0.807 & NS \\
\hline Mn (mg) & $1.6 / 2.2^{*}$ & 2.22 & 2.017 & NS \\
\hline Iodine $(\mu \mathrm{g})$ & 95 & 75.953 & 87.634 & NS \\
\hline Vitamin A $(\mu \mathrm{g})$ & $490 / 630 *$ & 1326.444 & 1090.818 & NS \\
\hline Retinol $(\mu \mathrm{g})$ & - & 291.845 & 322.249 & NS \\
\hline Beta-carotene $(\mu \mathrm{g})$ & - & 6019.765 & 4412.423 & NS \\
\hline Vitamin E (mg) & $8 / 10^{*}$ & 4.746 & 5.468 & NS \\
\hline Thiamine (mg) & $0.9 / 1.0 *$ & 0.797 & 0.971 & NS \\
\hline Riboflavin (mg) & $0.9 / 1.1^{*}$ & 1.198 & 1.311 & NS \\
\hline Niacin (mg) & $11 / 12^{*}$ & 16.923 & 22.488 & NS \\
\hline Vitamin B6 (mg) & $1 / 1.1^{*}$ & 1.727 & 2.115 & NS \\
\hline Vitamin C (mg) & $55 / 65^{*}$ & 111.643 & 97.38 & NS \\
\hline Folate $(\mu \mathrm{g})$ & 330 & 193.528 & 186.97 & NS \\
\hline Vitamin B12 $(\mu \mathrm{g})$ & 2 & 2.191 & 3.116 & NS \\
\hline Vitamin D $(\mu \mathrm{g})$ & 15 & 1.185 & 1.563 & NS \\
\hline
\end{tabular}

NS - not statistically significant

* with a distinction between sex and age

Table 4. Comparison of the average percentage of energy from nutrients

\begin{tabular}{|l|c|c|c|}
\hline \multicolumn{1}{|c|}{ Factor } & $\begin{array}{c}\text { Reference range } \\
(\%)\end{array}$ & Girls & Boys \\
\hline Protein (\%) & $10-20$ & 14.239 & 16.774 \\
\hline Lipids \% & $20-35$ & 29.752 & 26.438 \\
\hline Carbohydrates \% & $45-65$ & 56.009 & 56.788 \\
\hline
\end{tabular}

\section{DISCUSSION}

Celiac disease is an autoimmune disease affecting up to $1 / 100$ of the world's population. This is one of the most common forms of malabsorption. The only form of treatment is the strict use of a gluten-free diet $[1,41]$. Alzaben et al. [1] in study showed that the challenge for patients using a gluten-free diet is both its cost, which can be up to $50 \%$ higher than the costs of a traditional diet containing gluten and ensuring adequate nutritional value. Also, meals outside the home is a big problem for patients. In addition, there is concern about contamination of naturally gluten-free products at each stage of the production process, which may contribute to the unconscious intake of harmful protein and thus to symptoms $[8,19]$. Ferster et al. [8] noted in their study that the disadvantage reported by parents was the labeling of food and especially the presence of gluten in potentially gluten-free products. In products, gluten is used as a cheaper substitute for animal protein. A study conducted by Rilley et al. [32] involving 142 children between the age of 13 and 19 years of age showed in some patients the appearance of overweight and obesity, despite the normal values of body weight in the diagnosis of the disease. However, some patients with initially high body weight after using a gluten-free diet reduced or even achieved normal body weight.

In our own study it was shown that $70 \%$ of patients are around 50 percentile, which indicates a general good nutritional status. Similarly, in studies by Radlovic et al. [31] 70\% of respondents showed a beneficial nutritional status after using a gluten-free diet. In the present study, the percentage of energy intake of 
protein, fat and carbohydrates in both groups was within the norm. The opposite results were obtained in a study conducted by Mariani et al. [23] protein and fat were consumed in excessive amounts, which prevented malnutrition. However, as in our study, the diet was low in fiber, iron and calcium. As in the above study, patients consumed insufficient quantity of fiber. Its content in the diet did not exceed $16 \mathrm{~g} / \mathrm{d}$ with recommendations for celiac disease of 20-35 g/d [39]. The results of these tests correspond to the results obtained by other authors [20]. Insufficient intake of calcium reported in the present study, confirmed the results of Zuccotti et al. [41] and Alzaben et al. [1], also be carried out in pediatric patients. Ohlund et al. [27] also observed low intake of this ingredient in the diet of patients, however, despite this, the intake was higher than in the healthy control group. Higher intakes may be caused by food fortification or calcium supplementation prescribed by a doctor.

The low intake of vitamin D observed in the study and hypocalcemia lead to increased bone resorption. Enteropathy predisposes to the appearance of osteoporosis in the future. However, the bone mineral density improves after the introduction of a gluten-free diet, also the bone growth processes normalize [3]. Therefore, early diagnosis in children and exclusion of gluten from the diet will enable them to achieve the correct peak bone mass [31].

Low magnesium intake may predispose to the development of behavioral disorders, growth retardation, as well as cardiovascular dysfunction [27]. The deficiencies of this element in the diet were observed by Kautto et al. [14], and Balmatekin et al. [2]. This study confirmed this relationship. Rujner et al. [33] showed that this unbalanced diet results from a deficiency of this element in both enteropathic and healthy people.

Insufficient iron intake observed in the own study may result in anemia with a deficiency of this element. A gluten-free diet, although it improves the absorption of nutrients, is still poor in iron. Kautto et al. found low iron consumption mainly in boys [14, 25]. It is believed that especially in the period of recovery in people with enteropathy, intake values should be interpreted referring to recommendations for healthy people. Therefore, most studies of interpretation based on the ratio of the EAR. Values for the content of protein, carbohydrate and fat recommended for patients are respectively $15 \%, 25-30 \%$ and $55 \%$ [10, 28].

The good sources of nutrients that are excluded from the diet of patients with celiac disease are pseudocereals. Teff can supplement the content of essential amino acids as well as calcium, iron or magnesium as well as dietary fiber [36]. Quinoa is a rich source of folic acid. Rich in fiber are amaranth and buckwheat.
They also contain unsaturated fatty acids that support the prevention of cardiovascular disease. A good source of thiamine, iron and zinc is oats. However, despite the lack of harm to patients, it is extremely important to check the product designation, as it is often contaminated with gluten on the production line $[5,28]$. Buckwheat is a source of antioxidants, regulates blood cholesterol levels and is rich in many nutrients [7]. Unfortunately, in our study we observed little or no consumption of these products in the diet of patients. The menu was dominated by potatoes and white rice.

\section{CONCLUSIONS}

1. Incorrectly used gluten-free diet may be the cause of recurrence of disease symptoms.

2. Celiac disease does not affect the occurrence of malnutrition but contributes to the occurrence of quality deficiencies.

3. Chronic insufficient intake of fiber may predispose to constipation and complications associated with it.

4. The study group is exposed to osteoporosis and growth disturbances due to calcium and vitamin D deficiency.

5. The demonstrated deficiency of magnesium, zinc, vitamin $\mathrm{E}$ and folic acid in food rations may affect the occurrence of multi-system abnormalities.

\section{Conflict of interest}

The authors declare no conflict of interest.

\section{REFERENCES}

1. Alzaben A.S., Turner J., Shirton L., Samuel T.M., Persad R., Mager D.: Assessing nutritional quality and adherence to the gluten-free diet in children and adolescents with celiac disease. Can J Diet Pract Res 2015;76(2):56-63. doi:10.3148/cjdpr-2014-040.

2. Balamtekin N., Aksoy C., Baysoy G., Uslu N., Demir H., Köksal G., Saltı-Temizel I.N., Özen H., Gürakan F., Yüce A.: Is compliance with gluten-free diet sufficient? Diet composition of celiac patients. Turk J Pediatr 2015;57:374-9.

3. Capriles V.D., Martini L.A., Areas J.A.: Metabolic osteopathy in celiac disease: importance of a gluten-free diet. Nutr Rev 2009;67:599-606. doi: 10.1111/j.17534887.2009.00232.x.

4. Commission Implementing Regulation (EU) No $828 / 2014$ of 30 July 2014 on providing consumers with information on absence or reduced gluten content in food.

5. Daniewski W, Wojtasik A, Kunachowicz H.: Zawartość glutenu w bezglutenowych środkach spożywczych specjalnego żywieniowego przeznaczenia i innych produktach spożywczych. Gluten content in special dietary use gluten-free products and other food products. 
Rocz Panstw Zakl Hig 2010, 61(1): 51-55

6. De Re V., Magris R., Cannizzaro R.: New Insights into the Pathogenesis of Celiac Disease. Front Med 2017;4:1-11. doi: 10.3389/fmed.2017.00137.

7. Dziedzic K., Górecka D., Kobus-Cisowska J., Jeszka M.: Możliwości wykorzystania gryki w produkcji żywności funkcjonalnej [Possibilities of using buckwheat in the production of functional food. Nauka Przyroda Technologie 2010;4(2):1-7.

8. Ferster M., Obuchowicz A., Jarecka B., Pietrzak J., Karczewska K.: Trudności związane z przestrzeganiem diety bezglutenowej przez chorych na celiakię mieszkających na Górnym Śląsku [Difficulties related to compliance with a gluten-free diet for celiac patients living in Upper Silesia]. Pediatr Med Rodz 2015;11(4):410-8. DOI: 10.15557/PiMR.2015.0039 (in Polish).

9. Gadermayr M., Wimmer G., Kogler H., Vescei A., Merhof D., Uhl A.: Automated classification of celiac disease during upper endoscopy: Status quo and quo vadis. Comput Biol Med 2018, 1-6. doi: 10.1016/j. compbiomed.2018.04.020.

10. Gilissen J.W.J.L., van der Meer M.I., Smulders J.M.J.: Why oats are safe and healthy for celiac disease patients. Med Sci 2016;4(21). doi: 10.3390/medsci4040021.

11. Hollén E., Farnebäck M., Forslund T., Magnusson K.E., Sundqvist T., Fälth-Magnusson K.: Evaluation of Multiple Diagnostic Indicators in Comparison to the Intestinal Biopsy as the Golden Standard in Diagnosing Celiac Disease in Children. Med Sci 2016;4:20. doi: 10.3390/medsci4040020.

12. Jarosz M.: Normy żywienia dla populacji Polski [Nutritional standards for the population of Poland]. Warszawa: Instytut Żywności i Żywienia; 2017 (in Polish).

13. Jarosz M.: Praktyczny podręcznik dietetyki [A practical guide on nutrition]. Warszawa: Instytut Żywności i Żywienia; 2010 (in Polish).

14. Kautto E., Ivarsson A., Norstrom F., Hogberg L., Carlsson A., Hornell A.: Nutrient intake in adolescent girls and boys diagnosed with coeliac disease at an early age is mostly comparable to their non-coeliac contemporaries. J Hum Nutr Diet 2014;27:41-53. doi: 10.1111/jhn. 12125 .

15. Kelly C.P., Bai C.J., Liu E., Leffler D.A.: Advances in diagnosis and management of celiac disease. Gastroenterology 2015;148:1175-86. doi: 10.1053/j. gastro.2015.01.044.

16. Konturek S.J.: Gastroenterologia i hepatologia kliniczna [Gastroenterology and clinical hepatology]. Warszawa: Wyd. Lekarskie PZWL; 2006 (in Polish).

17. Krawczyński M.: Żywienie dzieci w zdrowiu i chorobie [Feeding children in health and illness]. Kraków: Wyd. Help-Med; 2008 (in Polish).

18. Krawiec P., Pac-Kożuchowska E.: Różny obraz kliniczny celiakii wśród dzieci [Different clinical picture of coeliac disease in children]. Prz Med. Uniw Rzesz Inst Leków 2012;2:193-199 (in Polish).

19. Lange E.: Produkty bezglutenowe na rynku polskim [Gluten-Free Products in the Polish Market]. Handel Wewnętrzny 2013;4(345):83-95 (in Polish).
20. Lange E.: Przetwory owsiane w diecie bezglutenowej. Oat products In gluten free diet. Rocz Panstw Zakl Hig 2007, 58(1), 103-109

21. Limanowska P., Kubiak J., Napieraj K.: Ocena opieki dietetycznej wśród osób chorych na celiakię i źródła informacji na temat diety bezglutenowej [Rating Dietetic Care Among Patients with Celiac Disease and the Source of Information on Gluten-Free Diet]. Piel Zdr Publ 2014;(4):351-6 (in Polish).

22. Malterre T.: Digestive and nutritional considerations in celiac disease: could supplementation help? Altern Med Rev 2009;14(3):247-57.

23. Mariani P., Viti M.G., Montuori M., La Vecchia A., Cipolletta E., Calvani L., Bonamico M.: The gluten-free diet a nutritional risk factor for adolescents with celiac disease? J Pediatr Gastroenterol Nutr 1998;27:519-23.

24. Myszkowska-Ryciak J., Harton A., Gajewska D.: Analiza wartości odżywczej i kosztów diety bezglutenowej w porównaniu do standardowej racji pokarmowe [Analysis of nutritional value and costs of gluten-free diet compared to standard food ration]. Med Og Nauk Zdr 2015;21(3):312-6. doi: 10.5604/20834543.1165359.

25. Naik R.D., Seidner D.L., Adams D.W.: Nutritional consideration in celiac disease and nonceliac gluten sensitivity. Gastroenterol Clin North Am 2018;47(1):139-54. doi: 10.1016/j.gtc.2017.09.006.

26. Niewinski M.M.: Advances in Celiac Disease and Gluten-Free Diet. J Am Diet Assoc 2008;108:661-72. doi: 10.1016/j.jada.2008.01.011.

27. Ohlund K., Olsson C., Hernell O., Ohlund I.: Dietary shortcomings in children on a gluten-free diet. J Hum Nutr Diet 2010;23:294-300. doi: 10.1111/j.1365277X.2010.01060.x

28. Penagini F., Dilillo D., Meneghin F., Mameli C., Fabiano V., Zuccotti V.G.: Gluten-free diet in children: an approach to a nutritionally adequate and balanced diet. Nutrients 2013;5:4553-65. doi: 10.3390/ nu5114553.

29. Pennisi M., Bramanti A., Cantone M., Pennisi G., Bella R., Lanza G.: Neurophysiology of the "celiac brain": Disentangling gut-brain connections. Front Neurosci 2017;11:498. doi: 10.3389/fnins.2017.00498.

30. Przetaczek-Rożnowska I., Bubis E.: Zboża bezglutenowe alternatywą dla osób chorych na celiakię [Gluten-free cereals as an alternative for celiac disease]. Kosmos Ser A 2016;65(1):127-140 (in Polish).

31. Radlović N., Mladenović M., Leković Z., Zivanović D., Brdar R., Radlović V., Ristić D., Pavlović M., Stojsić Z., Vuletić B., Djurdjević J., Gajić M.: Effect of glutenfree diet on the growth and nutritional status of children with coeliac disease. Srp Arh Celok Lek 2009;137:6327. doi: 10.2298/SARH0912632R.

32. Reilly R.N., Aguilar K., Hassid G.B., Cheng J., DeFelice R.A., Kazlow P., Bhagat G., Green P.H.: Celiac disease in normal-weight and overweight children: clinical features and growth outcomes following a gluten-free diet. J Pediatr Gastroenterol Nutr 2011;53(5):528-31. doi: 10.1097/MPG.0b013e3182276d5e.

33. Rujner J., Socha J., Syczewska M., Wojtasik A., Kunachowicz H., Stolarczyk A.: Magnesium status in 
children and adolescents with coeliac disease without malabsorption symptoms. Clin Nutr 2004;23(5):10749. doi: 10.1016/j.clnu.2003.10.018.

34. Saturni L., Ferretti G., Bacchetti T.: The gluten-free diet: Safety and nutritional quality. Nutrients 2010;2:1634. doi: 10.3390/nu20100016.

35. Scanlon S.A., Murray J.A.: Update on celiac disease - etiology, differential diagnosis, drug targets, and management advances. Clin Exp Gastroenterol 2011;4:297-311. doi: 10.2147/CEG.S8315.

36. Swora E., Stankowiak-Kulpa H., Mazur M.: Dieta bezglutenowa w chorobie trzewnej [Gluten-free diet in coeliac disease]. Now Lek 2009;78(5-6):324-9 (in Polish).

37. Szaflarska-Popławska A.: Patologia wątroby w celiakii - badania własne i przegląd piśmiennictwa [Liver injury in coeliac disease - own study and review of the literature]. Prz Gastroenterol 2011;6:259-66. doi: 10.5114/pg.2011.24309 (in Polish).
38. Szponar L, Wolnicka K, Rychlik E.: Album fotografii produktów i potraw [A photo album of products and dishes]. Warszawa: Instytut Zywności i Żywienia; 2008 (in Polish).

39. Theethira G.T., Dennis M., Leffler A.D.: Nutritional consequences of celiac disease and the gluten-free diet. Expert Rev. Clin Gastroenterol Hepatol 2014;8(2):1239. doi: 10.1586/17474124.2014.876360.

40. Włodarek D, Lange E, Kozłowska L, Głąska D.: Dietoterapia [Diet therapy]. Warszawa: Wyd. Lekarskie PZWL; 2015 (in Polish).

41. Zuccotti G., Fabiano V., Dilillo D., Picca M., Cravidi C., Brambilla P.: Intakes of nutrients in Italian children with celiac disease and the role of commercially available gluten-free products. J Hum Nutr Diet 2013;26:436-44. doi: 10.1111/jhn.12026.

Received: 24.06 .2019

Accepted: 23.09.2019 